Discourse and Communication for Sustainable Education, vol. 8, no. 2, pp. 94-102, 2017

\title{
Student Improvement by Applying the Numbered Heads Together (NHT) Approach to Basic Subjects of Vocational Competence in a Vocational High School in Indonesia
}

\author{
Veronika Marta Wora, Ranto Hadisaputro, \\ and Nugroho Agung Pambudi \\ University Negeri Sebelas Maret, Indonesia
}

\begin{abstract}
This research aims to improve the learning activity and achievement of a $10^{\text {th }}$ grade class made up of 30 students in a vocational high school located in the city of Surakarta, Indonesia, by applying the Numbered Heads Together (NHT) approach. The experiment was divided into two stages of four activities each: planning, implementation, observation, and reflection. The comparative descriptive procedure was then used to analyze the data. Prior to the researach implementation, the learning activity was relatively low in the pre-stage of the experiment. However, after the NHT approach, the percentage of active students increased in stage 1 and stage 2 . The result of the test also suggested a similar trend in student achievement. From this it can be concluded that the application of the NHT learning model improves engagement within the learning activity as well as the level of achievement.
\end{abstract}

Keywords: Numbered Head Together, vocational education, student achievement, sustainability.

\section{Introduction}

Education plays an integral role in the progress of a nation as it develops students' knowledge, as well as shaping their characters. Therefore, education should incorporate new and contemporary approaches to teaching (Zimele-Steina, 2013). The quality of the teacher is an important part of this effort as it provides educational sustainability (Salìte, Gedžūne, \& Gedžūne, 2009; Çoklar \& Yurdakul, 2017). Teachers are the most instrumental part of the learning process, given that they control class activities, therefore they must be able to plan and create learning programs and implement and lead learning activities, as well as interpret and use gathered data in order to improve them. It goes without saying that teachers are most certainly important. 
For the purposes of this study, the authors observed the conventional lecture method of a vocational high school in Surakarta City, Indonesia. This lecture method incorporates in the learning process the use of power point presentations and other forms of media. It was observed that while using this method, students were not actively involved in the learning process because they were not paying attention, and so their level of academic achievement was affected. A decision was made to trial a different learning model in the hope of overcoming this problem, and effectively improving student activeness and achievement. Several learning models have been developed for this purpose, cooperative learning being one of them. This method has been defined as pedagogy involving the use of groups whose members share interdependent goals and are assessed on individual outcomes (Ravenscroft, Buckless, \& Zuckerman, 1997). There are two potential disadvantages to the traditional group work, namely the "hitchhikers" and "workhorses", but these are discouraged by the two characteristics previously mentioned: positive interdependence, and individual accountability (Cottell \& Millis, 1992). Cooperative learning is also an effective teaching approach in achieving educational goals.

There have been various studies conducted on different methods of cooperative learning (Clinton \& Kohlmeyer, 2005; de Leng, Dolmans, Jöbsis, Muijtjens \& van der Vleuten, 2009; McMillen et al., 2016; Michael Nussbaum, 2008; O’Neal, McClellan \& Jarosinski, 2016; Pawattana, Prasarnpanich, \& Attanawong, 2014; Ruengtam, 2013; Siegel, 2005; Slavin, Hurley, \& Chamberlain, 2001), including: Numbered Heads Together approach (Leasa \& Corebima, 2017), Supplemental Instruction (Etter, Burmeister \& Elder, 2001), Jigsaw method (Buhr, Heflin, White, \& Pinheiro, 2014; Şengül \& Katranci, 2014a, 2014b), cooperative problem-based learning (CPBL) (Aziz, Yusof, Udin \& Yatim, 2013), and inquiry based science (Gillies, Nichols, Burgh, \& Haynes, 2014; Iliško, 2016).

The cooperative learning method chosen within this intervention was the Numbered Heads Together (NHT) approach. This approach creates the opportunity to share ideas as well as considering what the most appropriate answer to a problem or a question is. Furthermore, this approach encourages students to increase their cooperation. The NHT approach is designed to create more active responses from the students while teaching (McMillen et al., 2016). This study seeks to examine the effect of NHT as a cooperative learning strategy on the academic performance of a $10^{\text {th }}$ grade class in a vocational school located in Surakarta City, Indonesia. Its aim is to improve the student learning activeness and achievement in the Basic Vocational Competence subject.

\section{Methodology}

This research covers the study of student learning improvement by employing the NHT cooperative learning technique. The case study is a $10^{\text {th }}$ grade class of 30 students in a vocational high school located in Surakarta, Indonesia, during the 1st semester of 2017 (April 2017 - May 2017). The technological teaching facilities and environment in the classroom were controlled using this technique throughout the entire duration of the study. 


\section{The NHT aproach}

The NHT approach provides an opportunity for students to share ideas, as well as consider the most appropriate answer. The first step in this method is numbering the students and dividing the class into small groups. The number of groups depends on the number of concepts to be studied. For example, if a class consists of 30 students and there are 5 concepts to be studied, then there will be 5 groups of 6 people each, and each person in each group is numbered from 1 to 6 . After the groups are formed, each one will be provided with questions by the teacher. After this is done, everyone brings their "heads together" to discuss and to think about the questions they were given.

For the second step, the teacher picks a number and then calls the student that corresponds to that number from each group to come forward and answer the questions previously posed. This is done continuously until every student has been given the opportunity to explain their point of view. Depending on the answers, the teacher can then develop a more in-depth discussion, developing the students' knowledge.

\section{Instrument Validity Testing Technique}

To ensure the validity of the data, the researcher employs two data validation techniques:

a. Construct validity which is used to evaluate the student's learning activeness. This clarifies behavior by including the concept of ability. Since interest cannot be measured due to its abstractness, an indicator must be used. The indicator sheet showing pre-stage, stage 1 and stage 2 is presented in Table 1.

Table 1

Indicator Sheet Showing Pre-Stage, Stage 1 and Stage 2

\begin{tabular}{|c|c|c|c|}
\hline \multirow[b]{2}{*}{ No } & \multirow[b]{2}{*}{ Indicator } & \multicolumn{2}{|r|}{ Outcome } \\
\hline & & $\begin{array}{c}\text { Pre-Stage } \\
(\%)\end{array}$ & $\begin{array}{cc}\text { Stage } 1 & \text { Stage } 2 \\
(\%) & (\%)\end{array}$ \\
\hline 1 & Paying attention when material is explained & & \\
\hline 2 & Listening when the material is explained & & \\
\hline 3 & Are calm when the material is explained & & \\
\hline 4 & Finding information needed to work on the given problem & & \\
\hline 5 & Practice the given problem & & \\
\hline 6 & $\begin{array}{l}\text { Answering the questions the teacher has about the studied } \\
\text { material }\end{array}$ & & \\
\hline 7 & Acting according to teacher guidance / direction & & \\
\hline 8 & Actively discussing within the groups & & \\
\hline 9 & Commenting and concluding on the learning process & & \\
\hline & Summarizing learning materials in their own words & & \\
\hline
\end{tabular}

b. Content validity is used to evaluate the student learning achievement. The validity of the content refers to a test, therefore a set of questions is needed. This set of questions must be developed carefully, must be based on the knowledge and materials provided to the students and must be within their abilities. 


\section{Data Analysis Technique}

Data analysis serves to examine the data obtained through observation, documentation and examination. The data analysis used in this study is comparative descriptive analysis based on observation. This means that the data obtained from observing the student's learning activeness was analyzed by giving one point to the answers marked by the tick mark $(\sqrt{ })$ and zero points to the answers marked by the dash (-) in their written tests. The percentage $(p)$ of learning can be measured using this formula:

$$
p=\frac{\text { achievement score }}{\text { maximum score }} \times 100
$$

$\mathrm{P}=$ Student learning activity

Achievement score $=$ Number of achievement scores in one stage

Maximum score $=$ Maximum number of scores in one stage

In addition, any category is considered passed or completed if the percentage of students who passed is of at least $80 \%$.

The data obtained from the examination measuring the students' learning achievement can be analyzed by using a comparative descriptive analysis to compare the initial conditions prior to the use of the NHT method using the results obtained from stage I and stage II, so that the difference can be noted.

\section{Performance Indicators}

Performance indicators are very useful when it comes to observing improvements in student achievement. The performance indicators used in this study are presented in Table 2 .

Table 2

Performance Indicators

\begin{tabular}{lcl}
\hline \multicolumn{1}{c}{ Attribute Measured } & $\begin{array}{c}\text { Percentage of } \\
\text { Targeted Students }\end{array}$ & \multicolumn{1}{c}{ Method of measurement } \\
\hline $\begin{array}{l}\text { Learning activeness in the subject of } \\
\text { Basic Vocational Competence in }\end{array}$ & $80 \%$ & $\begin{array}{l}\text { The number of students who are } \\
\text { active and able to solve the problem } \\
\text { is observed during the process of } \\
\text { discussions and presentations. }\end{array}$ \\
\hline $\begin{array}{l}\text { Student achievement in the subject } \\
\text { of Basic Vocational Competence in }\end{array}$ & $80 \%$ & $\begin{array}{l}\text { It is measured from the results of } \\
\text { basic tests and calculated from the } \\
\text { number of students who are able to } \\
\text { meet the required score. }\end{array}$ \\
\hline
\end{tabular}

\section{Research procedure}

The research procedure adopted in this study can be divided in two stages: stage I and stage II. Every classroom meeting during both of these stages lasted approximately 45 minutes. The approach consisted of four activities: (1) planning, (2) implementation, (3) observation, and (4) reflection. A diagram of the research procedure is presented in Fig. 1. 


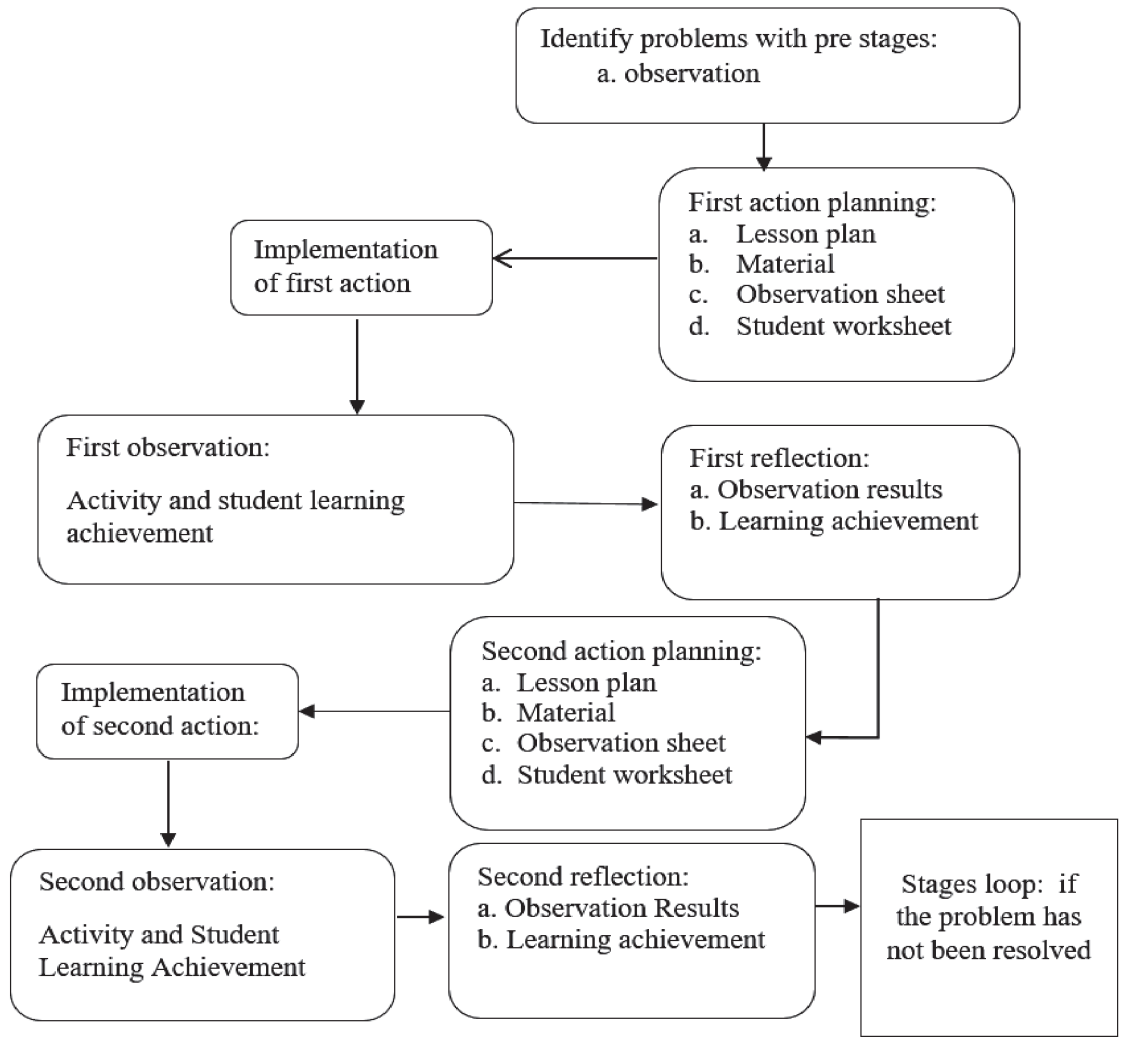

Figure 1. Schematic Showing the Research Procedures

\section{Results and Discussion}

The state of student activeness in the subject of Basic Vocational Competence can be seen in Table 3 .

Table 3

The Activity of Student Learning in Pre-Stage, Stage 1 and Stage 2

\begin{tabular}{ccc}
\hline \multicolumn{3}{c}{ Student Learning Activity } \\
\hline Action & Number of Students Passed & Percentage $\%$ \\
\hline Pre Stage & 10 & 34.48 \\
\hline Stage 1 & 10 & 71.43 \\
\hline Stage 2 & 25 & 86.21 \\
\hline
\end{tabular}

Table 3 presents the data on the student activeness, before and after Stage I and Stage II. There is visible improvement at each stage level.

The data presented in Fig. 2 shows that during Pre-stage 10 (34.48\%) out of 29 students met the minimum requirements for activeness during the use of the conventional lecture method. On the other hand, 19 students $(65.52 \%)$ out of 29 did not show activeness during the class. In the first stage of applying the NHT method, there was an 
increase in student activeness, although the target of $80 \%$ was not achieved. This may be attributed to students who lack enthusiasm during discussions or are easily distracted. The results obtained from observation show that $10(71.43 \%)$ out of 14 students were active during the learning activities, and the remaining 4 students $(28.57 \%)$ were inactive during the process. This observation was taken into consideration and used for improving the next stage.

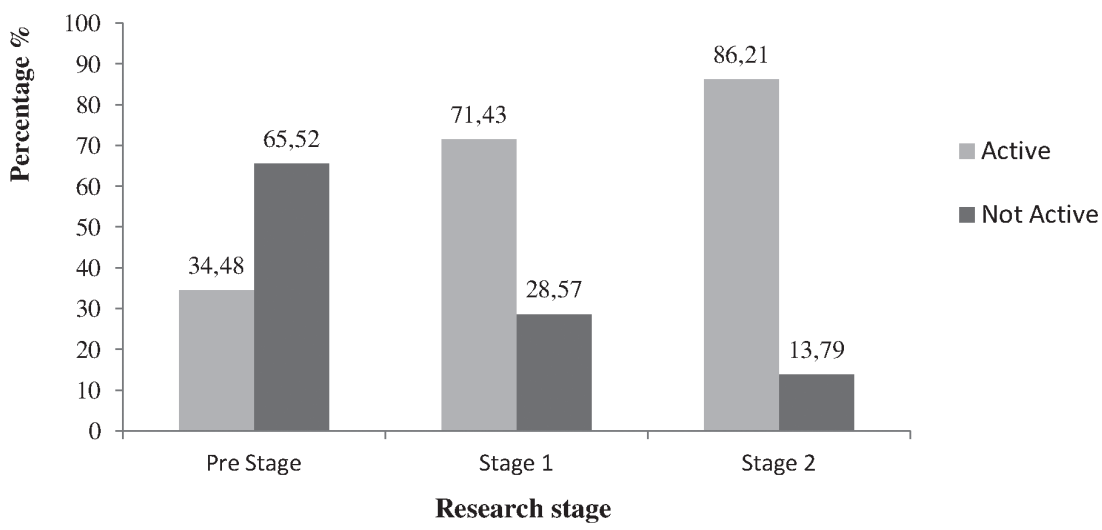

Figure 2. Comparison of student activity in pre-stage, Stage 1 and Stage 2

Results show that during Stage 225 (86.21\%) out of 19 students showed activeness during the learning activities, while the remaining $4(13.79 \%)$ students were still inactive. During the pre-stage, $34.48 \%$ of the students were active, the percentage raising to $71.43 \%$ in Stage 1 and to $86.21 \%$ in Stage 2 . These results obtained on student achievement are presented in Table 4.

Table 4

Student Learning Achievement in Pre-Stage, Stage 1 and Stage 2

Student achievement

\begin{tabular}{ccc}
\hline Action & Number of Students Passed & Percentage $\%$ \\
\hline Pre Stage & 11 & 37,93 \\
\hline Stage 1 & 10 & 71,43 \\
\hline Stage 2 & 25 & 86,21 \\
\hline
\end{tabular}

In the pre-stage, 29 out of 30 students took the evaluation test and the results revealed that 11 students $(37.93 \%)$ passed, while the remaining 18 students $(62.07 \%)$ failed. After employing the NHT technique during Stage 1, 14 students took the written test. The results showed that 10 students $(71.43 \%)$ passed the test, while 4 students $(28.57 \%)$ failed. Although the $80 \%$ target was not achieved in Stage 1, there was a significant improvement. During Stage 2, 29 students took the test out of which 25 students $(86.21 \%)$ passed and 4 students $(13.79 \%)$ did not. This shows that the student learning levels in the subject of Basic Vocational Competence not only increased, but also exceeded the pre-set target of $80 \%$ from the beginning of the study (Fig. 3 ). 


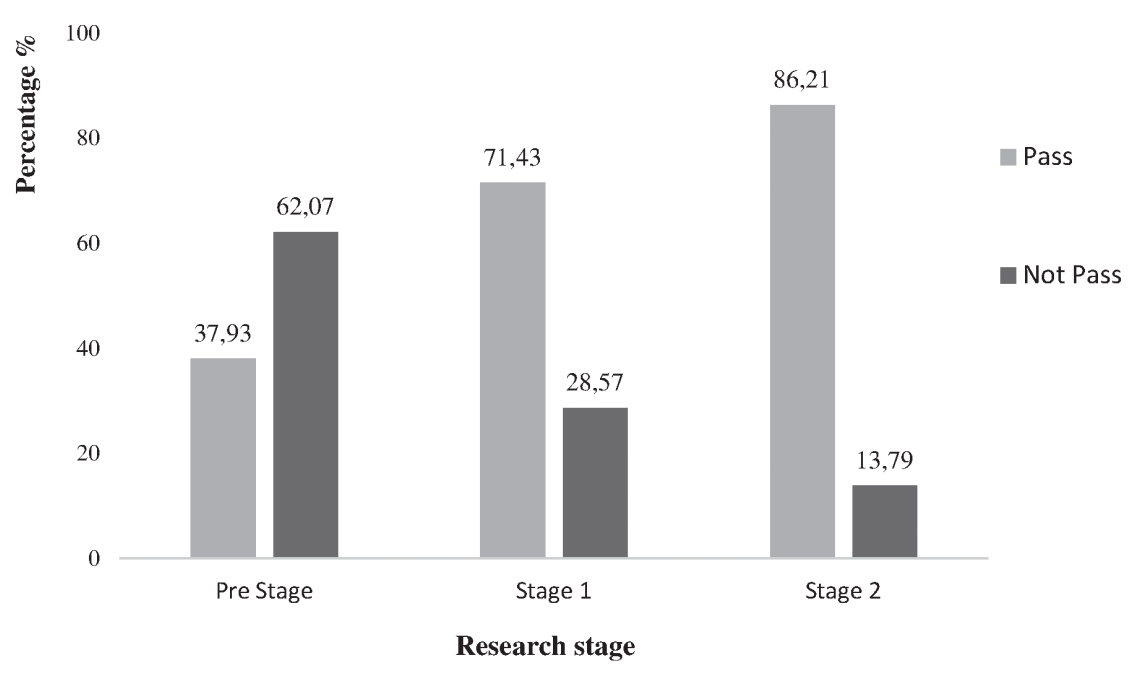

Figure 3. Comparison of Student Learning Achievements Pre-Stage, Stage 1 and Stage 2

\section{Conclusion}

The application of the NHT cooperative learning model improved the activeness as well as the learning achievement of the 10th grade students in the subject of Basic Vocational Competence in a vocational school in Surakarta, Indonesia. By applying this learning model, students are held accountable for their conclusions and it is easier for them to master the teaching materials because they have an active role in the process.

An increase in the student learning activity can be seen between all stages. Initially, 10 out of 29 students passed the test during the pre-stage. When NHT was applied in the first stage, 10 out of 14 students in attendance passed their test, as they began to be more active in the learning process. During the second stage, there was a further increase, with 25 out of 29 students passing the test. This suggests that NHT provides a more exciting learning environment as it is discussion based, making the students figure out a way to answer the questions posed by their teacher with the help of their classmates. This way, the learning process is not only more self-involved, but also more interesting to the students, which in turn contributes to increased activeness, a fact reflected by the students' test results.

\section{Reference}

Aziz, A. A., Yusof, K. M., Udin, A., \& Yatim, J. M. (2013). Development of students' knowledge-behavioural changes in relation to sustainability through a case study. Procedia - Social and Behavioral Sciences, 102, 568-576. doi: 10.1016/j.sbspro. 2013.10.773

Buhr, G. T., Heflin, M. T., White, H. K., \& Pinheiro, S. O. (2014). Using the jigsaw cooperative learning method to teach medical students about long-term and postacute care. Journal of the American Medical Directors Association, 15(6), 429434. doi: 10.1016/j.jamda.2014.01.015 
Cakula, S. (2011). Technological support and problem-based learning as a means of formation of student's creative experience. Discourse and Communication for Sustainable Education, 2(1), 46-55. doi: 10.2478/v10230-011-0003-5

Clinton, B. D., \& Kohlmeyer, J. M. (2005). The effects of group quizzes on performance and motivation to learn: Two experiments in cooperative learning. Journal of Accounting Education, 23(2), 96-116. doi: 10.1016/j.jaccedu.2005. 06.001

Çoklar, A. N., \& Yurdakul, I. K. (2017). Technology integration experiences of teachers. Discourse and Communication for Sustainable Education, 8(1), 19-31.

Cottell, P. G., \& Millis, B. J. (1992). Cooperative learning in accounting. Journal of Accounting Education, 10(1), 95-111. doi: 10.1016/0748-5751(92)90019-2

de Leng, B. A., Dolmans, D. H. J. M., Jöbsis, R., Muijtjens, A. M. M., \& van der Vleuten, C. P. M. (2009). Exploration of an e-learning model to foster critical thinking on basic science concepts during work placements. Computers \& Education, 53(1), 1-13. doi: 10.1016/j.compedu.2008.12.012

Etter, E. R., Burmeister, S. L., \& Elder, R. J. (2001). Improving student performance and retention via supplemental instruction. Journal of Accounting Education, 18(4), 355-368. doi: 10.1016/S0748-5751(01)00006-9

Gillies, R. M., Nichols, K., Burgh, G., \& Haynes, M. (2014). Primary students's scientific reasoning and discourse during cooperative inquiry-based science activities. International Journal of Educational Research, 63, 127-140. doi: 10.1016/j.ijer.2013. 01.001

Iliško, Dz. (2016). Inquiry-based educational course in higher education towards sustainable communities: A case study. In Leal Filho W., \& Pace P. (Eds.). Teaching education for sustainable development at university level, (pp. 125-145). doi: 10.1007/978-3-319-32928-4_9

Leasa, M., \& Corebima, A. D. (2017). The effect of numbered heads together (NHT) cooperative learning model on the cognitive achievement of students with different academic ability. Journal of Physics: Conference Series, 795(1), 012071. doi: 10.1088/1742-6596/795/1/012071

McMillen, C., Mallette, B., Cynthia, S., Rey, J., Jabot, M., Michielli-Pendl, J., \& Maheady, L. (2016). Effects of numbered heads together on the science quiz performance of the 9th grade students. Journal of Evidence-Based Practices for Schools, $15(1), 65-80$.

Michael Nussbaum, E. (2008). Collaborative discourse, argumentation, and learning: Preface and literature review. Contemporary Educational Psychology, 33(3), 345359. doi: 10.1016/j.cedpsych.2008.06.001

O’Neal, P. V., McClellan, L. C., \& Jarosinski, J. M. (2016). A new model in teaching undergraduate research: A collaborative approach and learning cooperatives. Nurse Education in Practice, 18, 80-84. doi: 10.1016/j.nepr. 2016.03.008

Pawattana, A., Prasarnpanich, S., \& Attanawong, R. (2014). Enhancing primary school students' social skills using cooperative learning in mathematics. Procedia-Social and Behavioral Sciences, 112, 656-661. doi: 10.1016/j.sbspro.2014.01.1214

Ravenscroft, S. P., Buckless, F. A., \& Zuckerman, G. J. (1997). Student team learning replication and extension. Rochester, NY: Social Science Research Network. Retrieved from https://papers.ssrn.com/abstract $=46571$ 
Ruengtam, P. (2013). Modeling of cooperative/collaborative learning technique: A case study of interior architectural program. Procedia-Social and Behavioral Sciences, 105, 360-369. doi: 10.1016/j.sbspro.2013.11.038

Salīte, I. G. Gedžūne, I., \& Gedžūne, I. (2009). Educational action research for sustainability: Seeking wisdom of insight in teacher education. Journal of Teacher Education for Sustainability, 11(2): 14-30. doi: 10.2478/v10099-009-0037-y

Şengül, S., \& Katranci, Y. (2014a). Effects of jigsaw technique on mathematics selfefficacy perceptions of seventh grade primary school students. Procedia - Social and Behavioral Sciences, 116, 333-338. doi: 10.1016/j.sbspro.2014.01.217

Şengül, S., \& Katranci, Y. (2014b). Effects of jigsaw technique on seventh grade primary school students' attitude towards mathematics. Procedia-Social and Behavioral Sciences, 116, 339-344. doi: 10.1016/j.sbspro.2014. 01.218

Siegel, C. (2005). An ethnographic inquiry of cooperative learning implementation. Journal of School Psychology, 43(3), 219-239. doi: 10.1016/j.jsp.2005.04.005

Slavin, R. E., Hurley, E. A., \& Chamberlain, A. M. (2001). Cooperative learning in schools. In N. J. Smelser \& P. B. Baltes (Eds.), International Encyclopedia of the Social \& Behavioral Sciences (pp. 2756-2761). Oxford: Pergamon. doi: 10.1016/ B0-08-043076-7/02415-3

Zimele-Steina, I. (2013). Latvian piano teachers' views on an ideal teaching aid for pupils - young pianists. Discourse and Communication for Sustainable Education, 4, 43-49.

Correspondence relating this article should be addressed to Veronika Marta Wora, Department of Mechanical Engineering Education, Universitas Negeri Sebelas Maret, Jl. Ir. Sutami No. 36A, Kota Surakarta, Jawa Tengah 57126, Indonesia. Email: agung.pambudi@staff.uns.ac.id 